\title{
The Advantages of Budgets: A Survey of Macedonian Legal Entities
}

\author{
Dusica Stevcevska-Srbinoska \\ School of Business Economics and Management, University American College Skopje \\ Blvd. III Makedonska Brigada 60, 1000 Skopje, R. Macedonia
}

Tel: 389-2246-3156_E-mail: dusica@uacs.edu.mk

Received: December 10, 2017 Accepted: December 29, 2017

doi:10.5296/ber.v8i2.12266 URL: https://doi.org/10.5296/ber.v8i2.12266

\begin{abstract}
By surveying legal entities headquartered in the FYR Macedonia, this research investigates the relationship between entity size, the independent variables and the adoption of budgeting, the dependent variable. The study also looks at the perceived advantages and disadvantages of budgeting. In order to obtain basis for the field research, existing literature and empirical results were examined. Then, a survey was carried out by contacting managers and finance staff from the manufacturing, merchandising and service segments. The field data came from a sample of 52 respondents, forming a response rate of 61 percent. The empirical findings indicate that the advantages of using budgets far outweigh the disadvantages and that Macedonian enterprises do not consider using other planning tools as alternative to budgets. Furthermore, the questionnaire demonstrated that there is a positive relationship between company size and the adoption of budgeting practices. This research suggests that budgeting deserves further study given its massive use as a management control tool.
\end{abstract}

Keywords: Budgeting process, Advantages of budgets, Disadvantages of budgets, Technical aspects, Behavioral aspects, Macedonian companies

\section{Introduction}

As a widely-present management technique, budgets are used by organizations for numerous purposes such as cost control, pricing and product mix decisions, performance evaluation, target setting and employee motivation. Field observations depict an intense adoption of budgets by large and medium entities on a global scale. Budgets can be defined as the financial expression of the management plan of action for a certain time period in the future, and help coordinate the implementation of that time-delimited plan (Bhimani, Horngren, Datar, and Rajan 2015). Budgets are a management tool used for attaining organizational 
strategic goals. Hence, the success of budgeting is heavily dependent on determining organization goals, allocating the relevant responsibilities, and the implementation of that plan. The budgeting process starts with the outline of strategic objectives and developing forecasts for the impact of both operating and financing decisions where operating decisions relate to resource use while financing decisions center on the funds needed to procure scarce resources (Bhimani et al. 2015; Bierman 2010). The outcome of the process is the generation of a formal, comprehensive, organization-wide document labelled as budget.

According to Horngren, Datar, and Rajan (2012), entities follow through a set of premeditated steps in the course of their annual budgeting cycle. Namely, planning starts with a company-wide setting of organization and responsibility center objectives not disregarding past period results and anticipated new developments in the future. Then, top management provides lower-level management a set of financial and operational targets for measurement of results. The next step consists of data collection by management accountants and continues with inspection of variances to the plan in order to devise a corrective plan of action necessary to preserve profitability. Finally, management and management accountants initiate the new planning cycle by collecting personal experiences, organizational and market feedback, and market conditions.

In spite of the profuse upsides, this management accounting device has been subject to many assessments and has been criticized for technical and behavioral deficiencies in budgeting process set-up, lack of employee participation, misuse of budgets by managers for achievement of own financial benefits, and inability to sustain development in a dynamic environment. Given the opposing views in the world literature, this study explores the budgeting practices applied by Macedonian companies by looking at the budget adoption rate and its dependence on entity size, weighting of budgeting advantages versus budgeting disadvantages, and examining budgeting aspects in need of improvement. By conducting a questionnaire amongst legal entities with Macedonian headquarters, multiple important aspects of budgeting are put to test, starting with entity size, proceeding with inspection of perceived budgeting positives and drawbacks, but not disregarding technical and behavioral aspects of budget-setting in need of improvement. These areas encompass the set-up of budget model, tools used (software for data collection, analysis and projection), dedicated time and human resources, budget participation (together with susceptibility to create budgetary slack) and the use of budgets in performance measurement.

In the upcoming section, this paper will briefly investigate the advantages and disadvantages of budgeting across the relevant literature, and the opposing attitudes towards budgeting, which represents basis for this research. The paper then proceeds with description of the research objectives, research hypotheses, research methodology, research results, and ends with the conclusions and recommendations section.

\section{Literature Review}

As evidenced by accounting literature, budgets have long been used as an important management control tool (Pierce and O’Dea 1998; Bhimani et al. 2015; Horngren et al. 2012; Cornick, Cooper, and Wilson 1998; Scarborough, Nanni, and Sakuari 1991). However, in 
spite of positive attitudes, some researchers claim that budgets have a plethora of deficiencies and are inadequate for today's dynamic market environment (Kaplan and Johnson 1987; Stewart 1990).

Pierce and O'Dea (1998) assert that budgets are still relevant in today's business settings. According to their research conducted amongst Irish management accountants, traditional approaches continue to dominate management accounting systems, with particular emphasis on financial measures of control and performance evaluation. New management accounting techniques are rarely used, but are most often found in those companies reporting high usage of traditional techniques. Therefore, the authors conclude that these new systems are mainly applied for supplementing, rather than replacing, traditional techniques.

Researchers in favor of budgeting highlight several essential functions of budgets. In that sense, Bhimani et al. (2015) argue that budgets compel strategic planning, provide a means for performance measurement, facilitate communication and coordination of organizational activities, and have an influence on motivation and wider organizational processes. According to these authors, budgeting is put to its best use when combined with the company strategy. Also, budgeted performance evaluation helps overcome limitations of using past performance to evaluate actual results. Coordination makes managers reflect on the relationships across company departments and functions, and their contribution to the company as a whole. Communication, on the other hand, gets company objectives accepted and understood by everybody.

Without putting budgets to use, managers and employees cannot fully follow their growth and spending targets (Horngren et al. 2012). Horngren et al. claim that the budget is a common accounting tool used for implementing strategy, organization-wide communicating directions and goals by management, planning and controlling actions in order to competitively respond to customer needs. Budgeting measures the planned financial results against the planned organizational activities, while setting specific objectives and timelines, which is helpful for anticipating and avoiding hurdles. Horngren et al. indicate that budgets have been certified as a management device in setting up new businesses, augmenting their survival prospects.

Numerous authors examine the advantages of traditional budgeting when properly implemented claiming that the traditional approach has not lost meaning (Cardoş 2014; Waal, Hermkens-Janssen, and Ven 2011; Lucey 1996). In their work, they define budgets as a formal means for converting objectives into plans, for communicating and coordinating divisions and functions, promoting joint interests and boosting motivation. Moreover, budgetary control helps direct managerial effort towards areas of concern, aids in performance measurement, monitoring of expenditure, can improve efficiency and save costs. According to these researchers, budget monitoring provides feedback on indispensable adjustments to the plan which ultimately results with better cash and working capital management.

In their study, Popesko, Novak, Papadaki, and Hrabec (2015) examined the existing budgeting practices of Czech enterprises and the role of the budgeting systems for managing 
organizations. The authors find that although Czech companies showed an intention to somewhat modify the budgeting systems in use, they did not experience issues with flexibility and time spent on planning activities, and perceived a positive correlation between budgeting, strategy and performance.

Réka, Ştefan, and Daniel (2014) focus on ample literature review in order to determine whether firms perceive the proactive beyond budgeting approach as more useful than the reactive traditional budgeting. According to Réka et al., managers cannot discard budgeting because it is part of their business culture and are not yet prepared to adopt beyond budgeting concepts that demand a fundamental transformation of the management model in favor of decentralization.

Budgets are criticized for being used for measuring performance by managers, distorting long-term planning and encouraging misallocation of resources (Stewart 1990). According to Stewart, budgets are harmful when they become the end and achieving the budget numbers becomes the ultimate organization goal. This attitude is worsened when manager bonuses are at stake. Stewart argues that incentive pays make management jeopardize long-term sales and product value perception by offering discounts to achieve year-end targets, and overloading sales channels with stock at year-end and then taking it back at the beginning of the next reporting period in order to fulfil the budget figures. Furthermore, cost center owners are encouraged to put their cost centers ahead of the interests of other responsibility centers and of the entire company when performance pay is tied to cost center bottom line results. In the end, instead of controlling negative behavior, budgets end up blocking the business. Stewart suggests that overrunning budgets should be welcome when proper justification is provided.

Following an intense literature study, Neely, Sutcliff, and Heyns (2001) put forth the 12 most cited limitations of budgetary control : 1. Budgets are time-consuming; 2. Budgets constrain responsiveness and change; 3 . Budgets are not strategically focused and can be contradictory; 4. Budgets fail to add value; 5. Budgets focus on cost reduction rather than value creation; 6 . Budgets reinforce vertical lines of management and control; 7. Budgets do not support the adoption of new network structures; 8. Budgets encourage bad behavior; 9. Budgets are revised infrequently; 10. Budgets are built upon unconfirmed assumptions; 11. Budgets discourage inter-departmental knowledge distribution, and 12. Budgets make employees feel underestimated. Kaplan and Johnson (1987) questioned the ability of management accounting to develop and adapt in the dynamic business environment. According to these authors, a key challenge in relation to management accounting data is their ability to ensure relevant cost reduction and productivity information for managers. Another issue is raised by management need to obtain accurate product cost information whereby aggregate product costing in the accounting systems misguides product mix, product pricing, and competitor response decisions. Furthermore, management accounting reports disregard long-term orientation by encouraging managers to focus on short-term profit goals and to overrule investments that can benefit the long-run. Instead, old management accounting practices should be redesigned and new ones put in place in order to support the strategy and operations of the organization. 


\section{Research Objectives}

Given the insufficient field studies about the use of budgeting in FYR Macedonia, the aim of this research is to study the implementation of budgeting procedures by Macedonian firms. The administration of this management accounting device is of outmost significance for performing strategic planning, company-wide communication and coordination, and performance evaluation. As a result, the following primary research objectives can be outlined:

1. To determine the relationship between company size and budget adoption rate,

2. To weight budgeting advantages versus budgeting disadvantages, and

3. To identify and accentuate budgeting aspects in need of improvement.

\section{Research Hypotheses}

\subsection{Enterprise Size}

Enterprise size is often considered an important factor for adoption of budgeting as accounting management tool due to greater operating complexity of big businesses and their demanding management control needs. Consequently, the interrelationship between company size and company budgeting practices represents a topic of major research interest. Literature review reveals that strategic planning in small firms has low adoption rates. In this regard, Andrés, Fuente, and Martín (2015) carried out a survey in 2011 on a sample of 140 non-financial Spanish firms and found that size and industry are related to the frequency of use of certain capital budgeting techniques. Another study of small businesses in the Netherlands confirms that planning processes intensify with larger companies (Risseeuw and Masurel 1994). A study by Masurel and Smit (2000) of small Vietnamese firms indicated that in comparison to small entities, larger firms engage more in planning and resort to more sophisticated planning tools. Analyzing a sample of 248 small Austrian enterprises operating in multiple segments, Kraus, Harms, and Schwarz (2008) conclude that the time span for strategic planning in small and medium-sized entities might be shorter than for large companies. According to Danielson and Scott (2006), limited staffing and education background of some owners of small businesses partly explains why small firms do not often use refined management accounting tools. In their text, small firms are defined as enterprises with less than 250 employees. By collecting survey data compiled by the National Federation of Independent Business to analyze the capital budgeting practices of small firms, these authors discover that only 31 percent of their sample firms have a written business plan and conclude that small and large firms apply different capital budgeting practices. The on-line survey conducted in three consecutive years by Petkovski and Angelova (2014) encompassing a sample of 150 small and medium-sized Macedonian companies examined the reasoning and use of budgeting as a tool for starting or expanding operations. The results indicated an insufficient knowledge and adoption of this management accounting tool by SMEs. Moreover, even though the respondents claimed to know the benefits of business planning, they used this tool mainly for the purpose of acquiring finances. Hence, there was no clear indication that the tool will be used again for purposes different than financing. 
Other researchers (e.g. Bhidé 2000; Mintzberg 1993) stand for predominantly flexible planning processes and against formalized strategic planning in small and medium-sized enterprises. This literature review serves as a starting point for developing the first hypothesis:

Hypothesis one: Larger companies are more likely to use budgeting than smaller companies.

\subsection{Advantages versus Disadvantages of Budgeting}

There are contrasting attitudes towards the usefulness of budgeting in the world literature. In their study, Marginson and Ogden (2005) argue that managers confronted with an uncertain environment associated with role ambiguity may perceive the use of budgets as valuable. Hansen and Van der Stede (2004) - based on survey results obtained from 57 managers responsible for preparing the budget for their organizational unit - and Ahmad, Sulaiman, and Alwi (2003) - studying the use of budgets in Malaysian entities - support the multiple use of budgets as valuable planning and control mechanism. In his research paper, Sandalgaard (2012) indicates that there is a positive relationship between competition and the adoption of rolling forecasts amongst Danish companies.

However, authors like Bourmistrov and Kaarbøe (2013) accentuate the problems associated with the use of budgeting and detail on the analysis of two multinational companies that abandoned these instruments. This management control system redesign improved the organizational negotiation and learning processes, while promoting interaction with internal and external business surroundings. Neely et al. (2001) discuss the 12 weaknesses of traditional budgets by interviewing 15 leading companies on their best organizational practices. Hope and Fraser (cited in Bhimani et al. 2015, 446) argue strongly that "budgeting - as most corporations practice it - should be abolished". They criticize traditional budgeting and provide several proposals for change, such as aligning budgeting to strategy, tailoring the budget cycle to the purpose of budgeting, considering financial and non-financial aspects, unremitting performance improvement during the budget period, and use of $\mathrm{ABC}$ costing in cost reduction. Aside from setting forth the difficulties associated with current traditional budgeting practices, such as extended effort and duration, target setting based on internal rather than external competitive focus, and adoption of budget comfort margins, Waal (2005) analyzes the 12 principles of beyond budgeting. The author claims self-governance framework, supportive leadership, continuous strategy-setting efforts and fast delivery of information among others to be the core pillars of improved performance.

This contradictory literature evidence is used as basis for testing the second hypothesis:

Hypothesis two: Budgeting advantages outweigh budgeting disadvantages.

\subsection{Behavioral Issues}

Campbell (1985) explains that the core aim of the budget is to guide managerial effort companywide through planning, coordinating, measuring and rewarding towards the achievement of the organizational objectives. Yet, the budgeting process is guided by both technical and behavioral aspects that require proper understanding and management. 
Recognizing this dimension, Boon, Arumugam, Safa, and Baker (2007) put forth the social and organizational changes needed to support the budgeting process, especially in terms of guiding employees' attitudes and their commitment to work. From there, one can draw on the importance of people and behavioral aspects, emphasized in the 12 beyond budgeting premises (Hope and Fraser 2003; Neely, Bourne, and Adams 2003). Raghunandan, Ramgulam, and Raghunandan-Mohammed (2012) argue that a successful budgeting process cannot afford to disregard neither the technical nor the behavioral aspects in order to achieve organizational goals. While the technical element of budgeting is concerned with mathematical calculations of projected costs and expenses, the social component is a pre-condition to the success of the technical aspect of budgeting with the employment of people. Budgeting influences human behavior such as motivation and dysfunctional behavior. Hence, according to Raghunandan et al., the accounting techniques applied and the human relations in budgeting should not be divorced from each other. Hussey (1992) discusses the significance of the relationship between quality of plan and quality of strategy, not disregarding the importance of reflecting market conditions and company competence. Hansen, Otley, and Van der Stede (2003) state that time, process, and people are the downsides to traditional budgeting practices. The authors depict budgeting as a costly and lengthy process, lasting four or five months, and consuming up to 30 percent of a manager's time, thus adding very low value to the entity. Moreover, budgeting produces dysfunctional behavior, especially when performance measurement targets are unrealistic. In their research, George and Weimerskirch (1998), Bou and Beltrán (2005), and Eamets, Mygind, and Natalia (2008) say that the behavioral component of budgeting means engaging people to fulfil its technical aspect. Therefore, companies must be well aware that the effective application of any budget rests on employee commitment to the objectives and budget of their company.

This literature evidence forms the basis for testing the third hypothesis:

Hypothesis three: Behavioral issues will be the most common cause for dissatisfaction with the budgeting process.

\section{Research Methodology}

In order to collect the research data, a survey questionnaire comprised of 10 questions was prepared. The questionnaire consists of two kinds of questions:

- Multiple-choice questions, with possibility to choose from a predetermined response list. Also, a blank space was available in response to two questions if the selections were deemed to be insufficient.

- Likert-type questions, used to indicate level of agreement or disagreement in social science research. The Likert-type scale used was based on 5 points.

The questionnaire is organized into two sections. The first section observes entity characteristics by asking general information such as entity operation type, annual revenues, status of budget adoption, wrapping up with reasons for non-adoption. The first section sets on establishing a correlation between company size as company-specific factor and the disposition to budgeting as a tool. 


\section{$\triangle$ Macrothink}

Business and Economic Research

ISSN 2162-4860

2018, Vol. 8, No. 2

The second section seeks specification on budgeting techniques in use and investigates budgeting advantages and disadvantages as perceived by the respondents. The advantages are modelled upon Abdullah's Malaysian research (2008) and the survey employed by Lidia (2014) who investigated the Romanian academic and business environments, and concluded that in spite of their downsides, budgets are useful for companies. The disadvantages discussed in this survey are mostly adapted from the 12 weaknesses as defined by Neely et al. (2001). These two questions are semi-structured, allowing the surveyed individuals to select their response from a multitude of options or develop their own response if needed. Moreover, respondents were able to designate the perceived level of importance of budget advantages and disadvantages using a five-point Likert scale. Modelled upon Abdullah (2008), the last part of the second section investigates whether the respondents' companies plan to improve the current budgeting process or not, and to provide reasoning for their answer. Those who provide a positive response then focus on recommendations regarding future areas of improvement of budgeting practices, while the respondents who opt for a negative answer are asked to state why their organization is not set on altering the existing budgeting process.

Before resorting to the actual survey distribution, the questionnaire was pilot tested on a sample of subjects/qualified employees from several industries in order to avoid misreading of questionnaire items by the respondents. The received feedback was then used to filter the questions.

During the summer of 2017, 85 questionnaires were delivered randomly by hand or via e-mail to target respondents from companies varying on operations type and size doing business on the territory of FYR Macedonia, but excluding micro enterprises due to their highly limited scope of operations and limited adoption of sophisticated cost management and planning tools. The respondents are managers and senior finance department staff actively involved in business planning. The response rate was 61 percent or 52 questionnaires. No incomplete questionnaires were returned. Consequently, the useable response rate corresponds with the response rate.

SPSS program was used to carry out quantitative data processing. The SPSS analysis generated appropriate descriptive statistical evidence, including means, frequencies, standard deviations, t-test, chi-square, and ANOVA tests.

\section{Research Results}

This section presents the results of the conducted survey.

\subsection{Organization Characteristics}

In the opening section of the field survey, respondents were asked to classify their company according to the type of operations. According to the results, the majority of the survey participants come from the service sector. 
Table 1. Company segment according to operations

\begin{tabular}{|l|l|l|l|l|}
\hline & Frequency & Percent & Valid Percent & Cumulative Percent \\
\hline Manufacturing & 10 & 19,2 & 19,2 & 19,2 \\
\hline Merchandising & 13 & 25,0 & 25,0 & 44,2 \\
\hline Service & 29 & 55,8 & 55,8 & 100,0 \\
\hline Total & $\mathbf{5 2}$ & $\mathbf{1 0 0 , 0}$ & $\mathbf{1 0 0 , 0}$ & \\
\hline
\end{tabular}

Note: Data extracted from question 1 of the survey.

Table 1 shows that 56 percent operate in service industry, 19 percent of firms are from the manufacturing sector, while 25 percent are in the merchandising business.

\subsection{Enterprise Size}

One question sought to specify the size of the surveyed entities. The inquiry asked about the average annual gross revenues of the surveyed entities for 2015 and 2016 and guided the respondents to select one of two possible answers: less than 10 million euros, and 10 million euros or more. This item allowed for a distinction between smaller and larger companies based on the Macedonian Company Law whereby the classification of commercial entities into micro, small, medium, and large is based on three parameters: number of employees, annual revenues, and average total assets for the last two accounting years (Ministry of Economy, FYR Macedonia 2004). Selecting one parameter was essential for simplifying the classification of the surveyed firms while preserving the essence on the local legislation guidelines. Table 1 presents the answers to this question.

Table 2. Variable empiric frequencies: entity size (presented in rows) and bimodality of adoption status in correlation to the entity size (presented in columns)

\begin{tabular}{|c|c|c|c|c|}
\hline \multicolumn{2}{|c|}{ Average annual gross revenues } & \multicolumn{2}{|c|}{ Current budget adoption status } & \multirow{3}{*}{$\begin{array}{l}\text { Total } \\
29 \\
\end{array}$} \\
\hline & & \multirow{2}{*}{$\begin{array}{l}\text { No } \\
0\end{array}$} & \multirow{2}{*}{$\begin{array}{l}\text { Yes } \\
29\end{array}$} & \\
\hline 10mn EUR or more & Count & & & \\
\hline & $\%$ within Avg annual gross revenues & $0,0 \%$ & $100,0 \%$ & $100,0 \%$ \\
\hline & $\%$ within adoption status & $0,0 \%$ & $72,5 \%$ & $55,8 \%$ \\
\hline \multirow[t]{3}{*}{$<10 \mathrm{mn}$ EUR } & Count & 12 & 11 & 23 \\
\hline & $\%$ within Avg annual gross revenues & $52,2 \%$ & $47,8 \%$ & $100,0 \%$ \\
\hline & $\%$ within adoption status & $100,0 \%$ & $27,5 \%$ & $44,2 \%$ \\
\hline \multirow[t]{3}{*}{ Total } & Count & 12 & 40 & 52 \\
\hline & $\%$ within Avg annual gross revenues & $23,1 \%$ & $76,9 \%$ & $100,0 \%$ \\
\hline & $\%$ within adoption status & $100,0 \%$ & $100,0 \%$ & $100,0 \%$ \\
\hline
\end{tabular}

Note: Data extracted from questions 2 and 3 of the survey.

According to the frequencies shown in Table 2, all large entities practice budgets (29 out of 29 respondents in the sample), as opposed to 47.8 percent of smaller entities based on average annual gross revenues. Fisher's Exact Test indicates that the association between company size as measured by their average annual revenues and the adoption of budgeting is considerable given that the defined risk of error $1-\alpha$, i.e. $p=0,05$ is higher than the value of the realized level of risk of error, which equals $\mathrm{p}<0.001$. The details regarding the statistical testing of hypothesis one are provided in Table 3. 
Table 3. Fisher's exact test for company size: average revenues per year

\begin{tabular}{|l|l|l|l|l|l|l|}
\hline & Value & df & $\begin{array}{l}\text { Asymp. Sig. } \\
(2 \text {-sided })\end{array}$ & $\begin{array}{l}\text { Exact Sig. } \\
(2 \text {-sided })\end{array}$ & $\begin{array}{l}\text { Exact Sig. } \\
(1-\text {-sided })\end{array}$ & $\begin{array}{l}\text { Point } \\
\text { Probability }\end{array}$ \\
\hline Pearson Chi-Square & $19,670 \mathrm{a}$ & 1 &, 000 &, 000 &, 000 & \\
\hline Continuity Correctionb & 16,840 & 1 &, 000 & & & \\
\hline Likelihood Ratio & 24,340 & 1 &, 000 &, 000 &, 000 & \\
\hline Fisher's Exact Test & & & &, 000 &, 000 & \\
\hline Linear-by-Linear Association & $19,291 \mathrm{c}$ & 1 &, 000 &, 000 &, 000 &, 000 \\
\hline N of Valid Cases & 52 & & & & & \\
\hline
\end{tabular}

a. 0 cells $(0,0 \%)$ have expected count less than 5 . The minimum expected count is 5,31 .

b. Computed only for a $2 \times 2$ table

c. The standardized statistic is 4,392 .

The results confirm the existence of a statistically significant correlation between entity size and adoption of budgeting practices. The analysis demonstrates that big organizations face great complexity and expenses, and have a need for sophisticated management techniques such as budgeting as opposed to small firms which work with a less diversified product lines, target a smaller market portion and have less complex organizational structures subject to control. These observations are in line with the results reported by Risseeuw and Masurel (1994), Masurel and Smit (2000), Danielson and Scott (2006), Andrés, Fuente, and Martín (2015), and Petkovski and Angelova (2014).

Table 4 summarizes the reasons for absence of budgeting practices by non-adopters.

Table 4. Reasons for not adopting budgets

\begin{tabular}{|l|c|c|}
\hline & Number of times selected & $\%$ of Non-adopters \\
\hline Lack of knowledge & 5 & $41.7 \%$ \\
\hline Lack of human and financial resources & 7 & $58.3 \%$ \\
\hline Lack of technology tools/software & 8 & $66.7 \%$ \\
\hline We use other tools for planning and control & 6 & $50.0 \%$ \\
\hline No need to use this kind of tool & 10 & $83.3 \%$ \\
\hline Total entities: Non-adopters & $\mathbf{1 2}$ & \\
\hline
\end{tabular}

Note: Data extracted from question 4 of the survey. 12 entities do not use budgets.

As previously shown in Table 2, 23 percent of the overall respondents asserted that they do not use budgets. According to Table 4, the most prominent reason is the lack of need for this tool, which confirms the attitude that lower operations and organization complexity requires lesser use of management and control tools. The second most quoted reason for non-adoption is the poor availability of technological tools and equipment, which is especially lacking in smaller firms. Oftentimes, small organizations are deficient in adequate IT support/software, knowledge and experience with sophisticated management control tools and as a result they tend to rely on management guidance and experience for strategic direction. Hence, the third most cited reason for absence on budgeting being the application of other methods for planning and control purposes (8 points). Another issue of concern for non-adopters, mainly small enterprises, is their lack of resources, especially employees that can dedicate 
appropriate time and effort to planning tasks. Nonetheless, smaller organizations should not disregard the benefits such as planning, coordination, communication, financing, performance appraisal, competition and market positioning that the adoption of such systems can bring. Small organizations do not need to make big investments in sophisticated computer systems because their needs are reduced in comparison to those of large entities, so they should not fear that major transformations will be imposed aside from management support, proper training and employee time commitment. The least quoted reason for non-use of budgeting is knowledge deficiency on the tool, which can be related to the wide dissemination of information on management planning and control techniques at the university level and the availability of training sessions and seminars organized by professional associations and consulting firms in the country.

\subsection{Budgeting Advantages Outweigh Budgeting Disadvantages}

Section four titled "Research hypotheses" discussed the upsides and downsides of the budgeting process by focusing on the most frequently quoted characteristics presented in the relevant literature. The literature review indicated that budgets serve numerous purposes (Lidia 2014; Abdullah 2008). In that sense, the questionnaire contained two questions focusing on specific advantages and disadvantages of this management accounting tool. The first question sought to gauge which advantages of budgets are perceived as most valuable by Macedonian firms. In order to allocate proper weight, respondents were asked to rate the importance of the following 7 budget objectives on a 5-point Likert scale from 1 - "not important" to 5 - "ultimately important":

a. Planning, communication and coordination: The budget is a means of formal communication within the company. This tool coordinates the actions of various business functions towards forecasting the future and the achievement of common entity objectives.

b. Evaluation and motivation: The budget can help evaluate the actions of managers by focusing on the costs and revenues they control and are responsible for within their responsibility center. As a result, the budget can motivate supervisory staff by rewarding them for achieving budgeted expenditures or profit results.

c. Authorization and delegation: The budget empowers managers to manage expenditures and staff within their responsibility center budget boundaries. Extending responsibility to managers by involving them actively in the budget process can make targets more realistic and stimulate managers by making them identify with these goals.

d. Performance management and control: Budgets facilitate monitoring, controlling and investigating variances by comparing budget and actual results which guides future corrective action

e. Financing: Tool for acquiring additional financing from banks, investors, shareholders or owners, and other sources

f. Market positioning: Budgets help create value for customers while distinguishing the company from competitors 


\section{Macrothink}

Business and Economic Research

g. Profit maximization: Budgets determine operational direction and help manage cash and allocate resources productively

h. Other: Respondents were provided space for specifying favorable budget roles other than the ones listed in the question.

All the ratings were summed up accordingly. Given the ample list of advantages, the respondents attributed the highest score to the role of budgets to establish effective control (mean of 4.3250 and total score of 173 points). The second-rated characteristic was the planning feature (mean of 4.2250 and total score of 169 points), followed by profit maximization and investigation of variances in actual results (mean of 4.1 and total score of 164 points). The respondents also emphasized the evaluation and motivation benefits (157 points and a mean of 3.9250), authorization and delegation (total score of 149 and a mean value of 3.7250). Furthermore, budgets were accorded an important financing function (130 points and a mean value of 3.25). The market positioning role of budgets were perceived as somewhat less important given the total score of 129 points and the mean value of 3.2250. Table 5 summarizes these results, showing that the advantages of using budgets attain an overall score of 1071 points.

Table 5. Positive aspects of budgets

\begin{tabular}{|l|l|l|l|l|l|l|}
\hline & $\mathrm{N}$ & Minimum & Maximum & Sum & Mean & Std. Deviation \\
\hline $\begin{array}{l}\text { Planning, communication } \\
\text { and coordination }\end{array}$ & 40 & 2,00 & 5,00 & 169,00 & 4,2250 &, 65974 \\
\hline Evaluation and motivation & 40 & 2,00 & 5,00 & 157,00 & 3,9250 &, 91672 \\
\hline Authorization and delegation & 40 & 3,00 & 5,00 & 149,00 & 3,7250 &, 59861 \\
\hline $\begin{array}{l}\text { Performance management } \\
\text { and control }\end{array}$ & 40 & 3,00 & 5,00 & 173,00 & 4,3250 &, 65584 \\
\hline Financing & 40 & 1,00 & 5,00 & 130,00 & 3,2500 &, 95407 \\
\hline Market positioning & 40 & 2,00 & 4,00 & 129,00 & 3,2250 &, 57679 \\
\hline Profit maximization & 40 & 3,00 & 5,00 & 164,00 & 4,1000 &, 63246 \\
\hline Valid N (listwise) & 40 & & & & & \\
\hline
\end{tabular}

Note: Data extracted from question 6 of the survey.

The next analysis opted for categorizing the respondents in two sets: one group of unsatisfied respondents that advocate budget process improvements and a second group that stands for preserving current budgeting practices. This factor, needs for improvement, was then tested against the positive aspects of budgets to detect whether there is a significant difference between the means of the two groups. The following table displays the output of the ANOVA analysis. 
Table 6. ANOVA: Positives of budgets vs. promoters and opponents to changes

\begin{tabular}{|c|c|c|c|c|c|c|}
\hline \multirow{4}{*}{$\begin{array}{l}\text { Planning, communication } \\
\text { and coordination }\end{array}$} & & Sum of Squares & $\mathrm{df}$ & Mean Square & $\mathrm{F}$ & Sig. \\
\hline & Between Groups & 1,402 & 1 & 1,402 & 3,420 &, 072 \\
\hline & Within Groups & 15,573 & 38 & ,410 & & \\
\hline & Total & 16,975 & 39 & & & \\
\hline \multirow[t]{3}{*}{ Evaluation and motivation } & Between Groups & 4,002 & 1 & 4,002 & 5,285 & ,027 \\
\hline & Within Groups & 28,773 & 38 &, 757 & & \\
\hline & Total & 32,775 & 39 & & & \\
\hline \multirow{3}{*}{$\begin{array}{l}\text { Authorization and } \\
\text { delegation }\end{array}$} & Between Groups & 1,602 & 1 & 1,602 & 4,919 & ,033 \\
\hline & Within Groups & 12,373 & 38 & ,326 & & \\
\hline & Total & 13,975 & 39 & & & \\
\hline \multirow{3}{*}{$\begin{array}{l}\text { Performance management } \\
\text { and control }\end{array}$} & Between Groups &, 002 & 1 & ,002 & ,004 & ,951 \\
\hline & Within Groups & 16,773 & 38 & ,441 & & \\
\hline & Total & 16,775 & 39 & & & \\
\hline \multirow[t]{3}{*}{ Financing } & Between Groups & 1,927 & 1 & 1,927 & 2,181 & ,148 \\
\hline & Within Groups & 33,573 & 38 & ,884 & & \\
\hline & Total & 35,500 & 39 & & & \\
\hline \multirow[t]{3}{*}{ Market positioning } & Between Groups &, 015 & 1 &, 015 & ,044 &, 835 \\
\hline & Within Groups & 12,960 & 38 & ,341 & & \\
\hline & Total & 12,975 & 39 & & & \\
\hline \multirow[t]{3}{*}{ Profit maximization } & Between Groups & 2,160 & 1 & 2,160 & 6,107 & ,018 \\
\hline & Within Groups & 13,440 & 38 & ,354 & & \\
\hline & Total & 15,600 & 39 & & & \\
\hline
\end{tabular}

Note: Data extracted from questions 6 and 8 of the survey.

These figures show that there is a statistically significant difference in profit maximization, motivation and delegation features of budgeting as a management control tool between the two groups (advocates for budgeting process upgrade and preservation advocates) taken the significance values of $0.018,0.027$ and 0.033 accordingly (i.e. $\mathrm{p}<0.05$ ). The remaining four features display no significant difference across groups.

The second question related to budget evaluation asked the respondents to specify the perceived disadvantages of budgets. These 7 downfalls stated below were modelled upon the 12 weaknesses of traditional budgets discussed by Neely et al. (2001). In order to allot appropriate weight to the factors identified as problems in their firm, respondents used a 5-likert scale ranging from 1- "not important" to 5 - "ultimately important":

a. Budgets are time-consuming and fail to add value, particularly given the time and energy invested

b. Budgets constrain responsiveness and change

c. Budgets are not strategically focused and can be contradictory, especially given the focus on current-year profit as opposed to long-term financial stability

d. Budgets focus on cost reduction rather than value creation, making employees feel underestimated due to frequent employee cost cuts and lack of empowerment. Human resources are perceived as costs rather than long-term assets of value.

e. Budgets reinforce vertical lines of management and control, failing to support new network structures, such as decentralization and partnerships 


\section{MInstitute Macrothink}

Business and Economic Research

f. Budgets discourage inter-departmental knowledge distribution, encouraging manipulations and budgetary slack - setting easy targets in order to be rewarded a bonus at the end of the reporting period

g. Budgets are built upon unconfirmed assumptions, are revised infrequently, and become obsolete due to change in internal and/or external circumstances

h. Other: Respondents were provided space for specifying unfavorable budget roles other than the ones listed in the inquiry.

Once again, the answers were added up. At the peak of the valuation pyramid, the participants stressed that budgets are overly focused on cost reduction rather than value creation given the total score of 161 points and the mean value of 4.025 . According to the survey participants, the second largest disadvantage of budgets is the element of time (sum of 133 points, mean of 3.325) whereby the budgeting process is perceived as costly due to the lengthiness and effort of process completion. Thirdly, by focusing on controlling rather than empowering staff, budgets are claimed to reinforce vertical lines of management and control (sum of 121 points, mean of 3.025) and to promote centralized instead of decentralized network structures. Given the score of 119 points and mean of 2.975 , respondents feel that budgets encourage budgetary slack and discourage inter-departmental cooperation and knowledge sharing. This negative feature is closely followed by lack of flexibility and responsiveness for amending budgets when circumstances change (105 points, mean of 2.625). Rare budget revisions and use of unconfirmed assumptions in planning are perceived as less of an issue (98 points, mean of 2.45) The lack of strategic focus of budgets due to focus on short-term business results (sum of 96 points, mean value of 2.4) is at the bottom of the tested issues list. Table 7 depicts an overall score of 833 points in terms of difficulties related to preparing budgets.

Table 7. Negative aspects of budgets

\begin{tabular}{|l|c|r|r|r|r|r|}
\hline & $\mathrm{N}$ & Minimum & Maximum & Sum & Mean & Std. Deviation \\
\hline Time-consuming & 40 & 1,00 & 5,00 & 133,00 & 3,3250 & 1,28876 \\
\hline $\begin{array}{l}\text { Constrain responsiveness } \\
\text { and change }\end{array}$ & 40 & 1,00 & 5,00 & 105,00 & 2,6250 &, 89693 \\
\hline Not strategically focused & 40 & 1,00 & 5,00 & 96,00 & 2,4000 & 1,19400 \\
\hline $\begin{array}{l}\text { Focus on cost reduction } \\
\text { rather than value creation }\end{array}$ & 40 & 2,00 & 5,00 & 161,00 & 4,0250 &, 91952 \\
\hline Reinforce centralization & 40 & 1,00 & 4,00 & 121,00 & 3,0250 &, 91952 \\
\hline $\begin{array}{l}\text { No knowledge distribution; } \\
\text { Budgetary slack }\end{array}$ & 40 & 1,00 & 5,00 & 119,00 & 2,9750 & 1,34903 \\
\hline $\begin{array}{l}\text { Built upon unconfirmed } \\
\text { assumptions }\end{array}$ & 40 & 1,00 & 5,00 & 98,00 & 2,4500 & 1,01147 \\
\hline Valid N (listwise) & 40 & & & & & \\
\hline
\end{tabular}

Note: Data extracted from question 7 of the survey.

A sum of all points per category was calculated to determine whether the advantages of budgeting are perceived as more vital than the difficulties caused by preparing and using this tool. Overall, given the final score of 1071 points versus 833 points, it is apparent that the positives of budgeting outweigh the negatives. This outcome corresponds to the results reported by Marginson and Ogden (2005), Hansen and Van der Stede (2004), Ahmad, Sulaiman, and Alwi (2003), and Sandalgaard (2012). Hence, Macedonian commercial entities 
perceive budgets as a valuable management accounting method to implement and use, which confirm hypothesis two of this research.

The next analysis categorized the respondents in two sets: one group of unsatisfied respondents that advocate budget process improvements and a second group that stands for preserving current budgeting practices. This factor, needs for improvement, is tested against the negative aspects of budgets to detect whether there is a significant difference between the means of the two groups. The following table displays the output of the one-way analysis of variance.

Table 8. ANOVA test on Positive aspects of budgets and advocates for changes

\begin{tabular}{|c|c|c|c|c|c|c|}
\hline & & Sum of Squares & df & Mean Square & $\mathrm{F}$ & Sig. \\
\hline \multirow[t]{3}{*}{ Time-consuming } & Between Groups & 27,735 & 1 & 27,735 & 28,454 &, 000 \\
\hline & Within Groups & 37,040 & 38 & ,975 & & \\
\hline & Total & 64,775 & 39 & & & \\
\hline \multirow{3}{*}{$\begin{array}{l}\text { Constrain responsiveness } \\
\text { and change }\end{array}$} & Between Groups & 7,935 & 1 & 7,935 & 12,864 & ,001 \\
\hline & Within Groups & 23,440 & 38 & ,617 & & \\
\hline & Total & 31,375 & 39 & & & \\
\hline \multirow{3}{*}{$\begin{array}{l}\text { Not strategically } \\
\text { focused }\end{array}$} & Between Groups & 38,507 & 1 & 38,507 & 85,604 & 000 \\
\hline & Within Groups & 17,093 & 38 & ,450 & & \\
\hline & Total & 55,600 & 39 & & & \\
\hline \multirow{3}{*}{$\begin{array}{l}\text { Focus on cost } \\
\text { reduction rather than } \\
\text { value creation }\end{array}$} & Between Groups & 7,935 & 1 & 7,935 & 12,042 & 001 \\
\hline & Within Groups & 25,040 & 38 & ,659 & & \\
\hline & Total & 32,975 & 39 & & & \\
\hline \multirow[t]{3}{*}{ Reinforce centralization } & Between Groups & 4,682 & 1 & 4,682 & 6,288 & , 017 \\
\hline & Within Groups & 28,293 & 38 &, 745 & & \\
\hline & Total & 32,975 & 39 & & & \\
\hline \multirow{3}{*}{$\begin{array}{l}\text { No knowledge } \\
\text { distribution; } \\
\text { Budgetary slack }\end{array}$} & Between Groups & 25,215 & 1 & 25,215 & 20,939 & ,000 \\
\hline & Within Groups & 45,760 & 38 & 1,204 & & \\
\hline & Total & 70,975 & 39 & & & \\
\hline \multirow{3}{*}{$\begin{array}{l}\text { Built upon unconfirmed } \\
\text { assumptions }\end{array}$} & Between Groups & 16,007 & 1 & 16,007 & 25,457 & ,000 \\
\hline & Within Groups & 23,893 & 38 & ,629 & & \\
\hline & Total & 39,900 & 39 & & & \\
\hline
\end{tabular}

Note: Data extracted from questions 7 and 8 of the survey.

Given that the $\mathrm{p}$ test score across all seven aspects is below 0.05, Table 8 indicates that there is a statistically significant difference across all budget shortfalls between the two groups (advocates for budgeting process upgrade and non-advocates). Hence, experts pushing for improvements in their firms' budgeting tactics have a statistically different opinion as to the negatives of budgets when compared to those that stand for preservation of the current processes.

\subsection{Budgeting Techniques}

Question five of the survey sought to determine which budgeting technique was predominantly used by the observed entities. 
Table 9. Budgeting techniques used

\begin{tabular}{|l|l|l|l|}
\hline & Frequency & Percent & Cumulative Percent \\
\hline Negotiated budget & 23 & $57,5 \%$ & 57,5 \\
\hline Top-down & 17 & $42,5 \%$ & 100,0 \\
\hline Bottom-up & 0 & $0 \%$ & 100,0 \\
\hline Total & 40 & $100,0 \%$ & $100,0 \%$ \\
\hline
\end{tabular}

Note: Data extracted from question 5 of the survey.

As illustrated in Table 9, the majority of the surveyed firms or 58 percent of adopters resort to the application of negotiated budget approach. The combined technique enables lower and middle management to prepare and submit individual budget inputs and requests, which are then merged and presented on the organizational level in front of the Board of directors. These budget totals and directions are then adjusted following the Board steering in order to achieve the common organizational goals and strategies. The second most frequently used technique is top-down budgeting whereby budget size is established by the Board of Directors to be then divided between departments and units. Bottom-up budgeting is the least present technique (no responses) whereby unit managers work out how much money they need to achieve their objectives and these amounts are combined to establish the Company's total budget.

However, there seems to be no significant association between the budgeting technique in use and the propensity to change or maintain the existing budgeting practices given that $\chi(1)=$ 2.462 and $\mathrm{p}=0.187$ (at the $\alpha=0.05$ level). The details behind the statistical testing of this association are provided in Table 10.

Table 10. Fisher's exact test: budgeting technique and susceptibility to change

\begin{tabular}{|l|l|l|l|l|l|l|}
\hline & Value & $\mathrm{df}$ & $\begin{array}{l}\text { Asymp. Sig. } \\
(2 \text {-sided })\end{array}$ & $\begin{array}{l}\text { Exact Sig. } \\
(2 \text {-sided })\end{array}$ & $\begin{array}{l}\text { Exact Sig. } \\
(1 \text {-sided })\end{array}$ & $\begin{array}{l}\text { Point } \\
\text { Probability }\end{array}$ \\
\hline Pearson Chi-Square & $2,462^{\mathrm{a}}$ & 1 &, 117 &, 187 &, 107 & \\
\hline Continuity Correction & 1,535 & 1 &, 215 & & & \\
\hline Likelihood Ratio & 2,534 & 1 &, 111 &, 187 &, 107 & \\
\hline Fisher's Exact Test & & & &, 187 &, 107 & \\
\hline Linear-by-Linear Association & $2,401^{\mathrm{c}}$ & 1 &, 121 &, 187 &, 107 &, 080 \\
\hline N of Valid Cases & 40 & & & & & \\
\hline
\end{tabular}

a. 0 cells $(0,0 \%)$ have expected count less than 5 . The minimum expected count is 6,38 .

b. Computed only for a $2 \times 2$ table

c. The standardized statistic is 1,549 .

In conclusion, the positive perception of budgets cannot be related to the dominant form of business planning in use by Macedonian companies.

\subsection{Behavioral Issues}

The literature and previous research review unveiled that although organizations nowadays still maintain their existing budgeting practices, many are not satisfied with some aspects of the budgeting system and would like to change it in order to make some improvements. 


\section{Macrothink}

Business and Economic Research

ISSN 2162-4860

2018, Vol. 8, No. 2

Consequently, the questionnaire included three questions to gauge whether the same opinion prevails amongst companies in Macedonia.

In that direction, the first question asked the respondents to state whether they would recommend their organization to make positive amendments to the existing budgeting system. Two mutually exclusive answers were made available: yes and no. If the answer was positive, the respondents were asked to state the reason why their company should change its budgeting approach. Using a 5-point Likert scale ranging from "strongly disagree" to "strongly agree", respondents indicated whether the changes should be driven by the need for improved (a) computer/software support and availability of relevant data, (b) budget precision and alignment to strategy, (c) process duration, (d) responsiveness to market circumstances, (e) employee participation, authorization and delegation, and (g) correlation between motivation and budget targets.

In case of a negative answer, the survey participants were asked to specify why their company should not consider changing the budgeting practices in use. A 5-point Likert scale ranging from "strongly disagree" to "strongly agree" was provided to respondents in order to specify whether their companies should maintain the existing budgeting process because (a) the budgeting process works well for the organization, (b) it is costly to change the budgeting method, (c) there is no suitable substitute tool for budgets, (d) too risky for the business, (e) the Board of Directors are opposed to the change, (f) lack of adequate computer/software technology, and (g) budget preparation fulfils regulatory requirements.

The survey results point out that out of 40 respondents who actively use budgeting, 37.5 percent recommend changes in the existing planning procedures, whereas the other 25 respondents feel that the current approach ought to be maintained. The corresponding frequencies are displayed in Table 11.

Table 11. Should the budgeting process be changed/improved in the future

\begin{tabular}{|l|l|l|l|}
\hline & Frequency & Percent & Cumulative Percent \\
\hline Yes & 15 & $37,5 \%$ & 37,5 \\
\hline No & 25 & $62,5 \%$ & 100,0 \\
\hline Total & 40 & $100,0 \%$ & \\
\hline
\end{tabular}

Note: Data extracted from question 8 of the survey.

Question 9 explored the budgeting aspects in need of improvement. The motives behind the desire to change are depicted in Table 12. 
Table 12. Budgeting aspects in need of improvement

\begin{tabular}{|l|l|l|l|l|l|l|}
\hline & $\mathrm{N}$ & Minimum & Maximum & Sum & Mean & Std. Deviation \\
\hline Software support & 15 & 2,00 & 5,00 & 45,00 & 3,0000 & 1,00000 \\
\hline Compatibility with the strategy & 15 & 3,00 & 4,00 & 49,00 & 3,2667 &, 45774 \\
\hline Reduced planning process duration & 15 & 3,00 & 5,00 & 69,00 & 4,6000 &, 73679 \\
\hline Market responsiveness & 15 & 2,00 & 5,00 & 58,00 & 3,8667 &, 91548 \\
\hline Focus on the long-term & 15 & 1,00 & 5,00 & 60,00 & 4,0000 & 1,46385 \\
\hline Employee participation & 15 & 4,00 & 5,00 & 70,00 & 4,6667 &, 48795 \\
\hline $\begin{array}{l}\text { Lack of motivation due to } \\
\text { unrealistic targets }\end{array}$ & 15 & 4,00 & 5,00 & 70,00 & 4,6667 &, 48795 \\
\hline Valid N (listwise) & 15 & & & & & \\
\hline
\end{tabular}

Note: Data extracted from question 9 of the survey.

The two core drivers behind the inclination to change are the insufficient employee involvement in budget target setting $(\mathrm{M}=4.667)$ and the interrelated lack of motivation as a result of unrealistic targets set by management $(M=4.667)$. Hence, the field scan clearly indicates that behavioral issues are in fact the most common cause for dissatisfaction with the budgeting process, which confirms the third research hypothesis. This conclusion is in line with the results reported by Boon, Arumugam, Safa, and Baker (2007), George and Weimerskirch (1998), Bou and Beltrán (2005), and Eamets, Mygind, and Natalia (2008). Aside from these two behavioral hurdles, the survey respondents that promote change state that there is a need to reduce the planning process duration $(\mathrm{M}=4.6)$ and to emphasize long-term direction given the predominant focus of budgeting on short-term results $(M=4.0)$. Furthermore, this group of participants emphasized the need to improve responsiveness to changes in the environment $(\mathrm{M}=3.8667)$. Interestingly, these companies did not justify their intention to change the budget due to poor compatibility with the strategy $(M=3.2667)$ and inadequate computer system support $(\mathrm{M}=3.0)$.

In the ending section of the questionnaire, the minority of the respondents opting for current planning process preservation were asked to evaluate why their organization should not make amendments to the existing practices. The results are presented in Table 13.

Table 13. Reasons why current budgeting practices should be preserved

\begin{tabular}{|l|r|r|r|r|r|r|}
\hline & $\mathrm{N}$ & Minimum & Maximum & Sum & Mean & Std. Deviation \\
\hline The planning process works well & 25 & 3,00 & 4,00 & 89,00 & 3,5600 &, 50662 \\
\hline $\begin{array}{l}\text { Too costly to change the } \\
\text { planning process }\end{array}$ & 25 & 1,00 & 4,00 & 76,00 & 3,0400 & 1,09848 \\
\hline No alternative to budgeting & 25 & 1,00 & 4,00 & 71,00 & 2,8400 & 1,14310 \\
\hline Risky for the business & 25 & 2,00 & 4,00 & 82,00 & 3,2800 &, 89069 \\
\hline $\begin{array}{l}\text { Lack of Management } \\
\text { Board support }\end{array}$ & 25 & 2,00 & 5,00 & 69,00 & 2,7600 & 1,01160 \\
\hline Inadequate computer system & 25 & 1 & 4 & 49 & 1,96 &, 790 \\
\hline Legal requirements & 25 & 1,00 & 3,00 & 41,00 & 1,6400 &, 63770 \\
\hline Valid N (listwise) & 25 & & & & & \\
\hline
\end{tabular}

Note: Data extracted from question 10 of the survey.

It is evident from the results that majority of the companies did not intend to change their budgeting practices in the near future as the current budgeting process works well for the 
company $(\mathrm{M}=3.56)$. The least promoted upside of budgets is compliance to legal requirements $(\mathrm{M}=1.64)$, which indicates that budgeting is not a pre-requisite by law but by personal choosing and need for direction.

\section{Conclusion and Recommendations}

The literature and earlier research overview show that budgeting is a time-consuming and expensive process. Improving employee participation, communication and coordination should be at the top of priorities of companies. To advance the planning process and gain a clear understanding of the future, divisions need to share information and work together. Without doubt firm size fuels the use of budgeting as a management tool given the business complexity and control needs of large companies. Nonetheless, there are opposed views on the usefulness of budgets as a management tool, whereby some authors promote budgets as a helpful technique, others advocate for abolishment, and some push for preservation of budgets but in an improved format. Building upon literature review, this study was focused on inspecting the adoption of budgets as a management accounting tool by the Macedonian commercial entities, analyzing the positive and negative aspects of budgeting, and the plans of entities to improve the existing budgeting system in the future. Hence, three propositions were formulated in order to investigate whether budgets are used equally by both larger and smaller firms, whether advantages of budgets outweigh the perceived disadvantages, and whether entities intend to upgrade the budgeting methods in use due to technical or behavioral shortcomings of budgeting techniques in their present form.

Summa summarum, the empirical results demonstrate the existence of a statistically significant correlation between entity size and use of budgets. Big organizations employ more refined controls than do small organizations due to extended use of resources and operational complexity. Also, this research confronts the perceived advantages and disadvantages of budgets in order to gauge whether the positive characteristics outweigh the negatives. The ending results demonstrated that this tool is more useful than harmful because of the perception of abundant upsides of budget adoption for businesses. Respondents emphasized the use of budgets in planning, control, coordination and communication between various business functions and departments. On the downside, respondents were not satisfied with the overemphasized focus on cost reduction rather than employee empowerment and the time consumed by planning, describing the procedure as costly and burdensome given the lack of resources. In relation to the engagement appreciation of human resources, the push for centralized decision-making and creation of slack were also pointed out as negatives of budgeting. By reducing the time invested in planning activities and improving the IT support through software upgrade and automation, organizations can relief some of the burden that planning imposes on employee responsibilities and time schedules to feel the benefits of improved budgeting. Market uncertainty coupled with lack of resources and competing priorities of the people involved in planning can hinder the upsides of budgeting on companies. Therefore, successful budgeting requires time, effort and resources along with congruence of budgeting and strategy. The Board of directors should refrain from using budgets as a blame game for punishing underperformance because this attitude can impede on cooperation and coordination among divisions. Instead, budgets should be applied as 
devices for guiding operating results, managerial effort and attention.

Lastly, as the world literature demonstrates a growing discontent of practitioners with budgets, this study examined whether Macedonian firms plan to preserve their current practices or are looking into changing them. The results show that the majority of companies intend to preserve the current system as they are satisfied with the existing practices. Respondents assert that abandoning budgets can be risky and costly to the business as they perceive no real alternative to this planning tool. However, behavioral aspects of budgeting must be improved, given that the study unveiled a remarkable interest in redesigning the budgeting approach in order to improve employee involvement, coordination and communication and pave the path for better companywide flow of information. Certainly, if budget changes are to be successful, senior management must show enthusiasm and commitment in order to motivate lower management and employees.

This study is the first study systematically analyzing the perceived advantages and disadvantages of budgeting as indicated by respondents from commercial entities headquartered in FYR Macedonia. Therefore, it is not without limitations. Due to the number of companies subject to interest, one can acknowledge that the sample may be too limited to be able to generalize on the results. Hence, researchers may work on expanding the study focus in order to include other firms from the Macedonian service, manufacturing and merchandising sectors. Moreover, the delivery of one portion of questionnaires by e-mail imposes a restriction to follow-up discussions and exhaustive respondent examination. Due to the impersonal nature of the survey, question misinterpretations could not be ruled out and details behind particular respondent attitudes could not be investigated. Also, as public-sector organizations were not encompassed in this empirical research, future studies could analyze the diffusion of budgeting and weight the upsides and downsides of this planning and control tool in the public sector as budget application extends beyond commercial legal entities.

Furthermore, as a follow-up to this study, the author can suggest that future research examines the relationship between planning and performance evaluation in order to deliver judgment between alternative planning behaviors. A deeper understanding of how the organizational set-up of the budgeting process influences performance and performance evaluation will help theoreticians and companies improve their budgeting process and thus obtain larger benefits from using this widespread management tool.

\section{References}

Abdullah, N. (2008). Budget: planning, control and organizational performance among public-listed companies in Malaysia. Master thesis, University of Malaya.

Ahmad, N. N. N., Sulaiman, M., \& Alwi, N. M. (2003). Are budgets useful? A survey of Malaysian companies. Managerial Auditing Journal, 18(9), 717-724. https://doi.org/10.1108/02686900310500479

Andrés, P. D., Fuente, G. D., \& Martín, P. S. (2015). Capital budgeting practices in Spain. Business Research Quarterly, 18, 37-56. https://doi.org/10.1016/j.brq.2014.08.002 
Bhidé, A. V. (2000). The Origin and Evolution of New Business. Oxford: Oxford University Press.

Bhimani, A., Horngren, C. T., Datar, S. M., \& Rajan, M. (2015). Management and Cost Accounting. London: Prentice Hall.

Bierman, H. (2010). An Introduction to Accounting and Managerial Finance: A merger of equals. Singapore: World Scientific Publishing Company. https://doi.org/10.1142/7318

Boon, O. K., Arumugam, V., Safa, M. S., \& Baker, N. A. (2007). HRM and TQM: association with job involvement. Personnel Review, 36(6), 939-962.

https://doi.org/10.1108/00483480710822445

Bou, J. C., \& Beltrán, I. (2005). Total Quality Management, High-commitment Human Resource Strategy and Firm Performance: An Empirical Study, Total Quality Management, 16(1), 71-86. https://doi.org/10.1080/1478336042000309875

Bourmistrov, A., \& Kaarboe. K. (2013). From comfort to stretch zones: A field study of two multinational companies applying "beyond budgeting" ideas. Management Accounting Research, 24(3), 196-211. https://doi.org/10.1016/j.mar.2013.04.001

Campbell, I. J. (1985). Budgeting is it a Technical or Behavioral Process?. Management Accounting, (February) 63(2), 66-70.

Cardoş, I. R. (2014). New Trends in Budgeting - a Literature Review. SEA - Practical Application of Science, 2(4), 483-489.

Cornick, M., Cooper, W., \& Wilson, S. (1988). How do companies analyze overhead. Management Accounting (June), 41-43.

Danielson, M. G., \& Scott, J. A. (2006). The Capital Budgeting Decisions of Small Businesses. Journal of Applied Finance, Financial Management Association International. Available at: https://www.highbeam.com/doc/1P3-1284870521.html

Eamets, R., Mygind, N., \& Natalia, S. (2008). The development of employee financial participation in Estonia. Baltic Journal of Management, 3(2), 218-231.

https://doi.org/10.1108/17465260810875523

George, S., \& Weimerskirch, A. (1998). Total Quality Management: Strategies and Techniques Proven at Today's Most Successful Companies, New York: John Wiley \& Sons, Inc.

Hansen, S. C., Otley, D. T., \& Van der Stede, W. A. (2003). Practice Developments in Budgeting: An Overview and Research Perspective. Journal of Management Accounting Research, 15, 95-116. https://doi.org/10.2308/jmar.2003.15.1.95

Hansen, S. C., \& Van der Stede, W. A. (2004). Multiple facets of budgeting: an exploratory analysis. Management Accounting Research, 15(4), 415-439.

https://doi.org/10.1016/j.mar.2004.08.001 
Hope, J., \& Fraser, R. (2003). Beyond Budgeting: How Managers Can Break Free from the Annual Performance Trap. Boston, Mass: Harvard Business School Press.

Horngren, C. T., Datar, S., \& Rajan, M. V. (2012). Cost Accounting: a managerial emphasis. New Jersey: Prentice Hall.

Hussey, D. E. (1992). Evaluating a business plan. Journal of Strategic Change, 1, 93-100. https://doi.org/10.1002/jsc.4240010206

Kaplan, R. S., \& Johnson, H. T. (1987). Relevance Lost: The Rise and Fall of Management Accounting. Boston: Harvard Business School Press.

Kraus, S., Harms, R., \& Schwarz, E. (2008). Strategic business planning and success in small firms. International Journal of Entrepreneurship and Innovation Management, 8(4), 381-396. https://doi.org/10.1504/IJEIM.2008.022311

Lidia, T. G. (2014). Difficulties of the Budgeting Process and Factors Leading to the Decisions to Implement this Management Tool. Procedia Economics and Finance, 15, 466-473. https://doi.org/10.1016/S2212-5671(14)00484-5

Lucey, T. (1996). Management Accounting. London: DP Publications.

Marginson, D., \& Ogden, S. (2005). Coping with ambiguity through the budget: the positive effects of budgetary targets on managers' budgeting behaviors. Accounting, Organizations and Society, 30(5), 435-456. https://doi.org/10.1016/j.aos.2004.05.004

Masurel, E., \& Smit, H. P. (2000). Planning behavior of small firms in Central Vietnam. Journal of Small Business Management, 38(2), 95-102.

Mintzberg, H. (1993). The pitfalls of strategic planning. California Management Review, 36(1), 32-47. https://doi.org/10.2307/41165733

Ministry of Economy, FYR Macedonia. (2004). Company Law. Available at: http://www.mse.mk/Repository/UserFiles/File/Misev/Regulativa/Zakoni\%20ENG/LL_CG_T radeCompanies_Dec_2004_E.pdf

Neely, A., Sutcliff, M. R., \& Heyns, H. R. (2001). Driving Value through Strategic Planning and Budgeting. New York, NY: Accenture.

Neely, A., Bourne, M., \& Adams, C. (2003). Better budgeting or beyond budgeting?. Measuring Business Excellence, 7(3), 22-28. https://doi.org/10.1108/13683040310496471

Petkovski, V., \& Angelova, B. (2014). Usage of business plans as a tool for starting and expanding businesses in Republic of Macedonia. Economic Development, 3, 29-44.

Pierce, B., \& O'Dea, T. (1998). An empirical study of management accounting practices in Ireland. Irish Accounting Review, 5(2), 35-66.

Popesko, B., Novak, P., Papadaki, S., \& Hrabec, D. (2015). Are the Traditional Budgets still Prevalent: the Survey of the Czech Firms Budgeting Practices. Transformations in Business and Economics, 14(3C), 42-59. 


\section{Macrothink}

Business and Economic Research

ISSN 2162-4860

2018, Vol. 8, No. 2

Raghunandan, M., Ramgulam, N., \& Raghunandan-Mohammed, K. (2012). Examining the behavioral aspects of budgeting with particular emphasis on public sector/service budgets. International Journal of Business and Social Science, 3(14), 110 - 117.

Réka, C. I., Ştefan, P., \& Daniel, C. V. (2014). Traditional budgeting versus beyond budgeting: a literature review. Economic Science Series, 23(1), 573-581.

Risseeuw, P., \& Masurel, E. (1994). The role of planning in small firms: empirical evidence from a service industry. Small Business Economics, 6, 313-322.

https://doi.org/10.1007/BF01108398

Sandalgaard, N. (2012). Uncertainty and budgets: an empirical investigation. Baltic Journal of Management, 7(4), 397-415. https://doi.org/10.1108/17465261211272157

Scarborough, P. A., Nanni, A., \& Sakuari, M. (1991). Japanese management accounting practices and the effects of assembly and process automation. Management Accounting Research, 2, 27-46. https://doi.org/10.1016/S1044-5005(91)70025-5

Stewart, T. A. (1990). Why budgets are bad for business. Fortune (June), 179-190.

Waal, A. (2005). Insights from practice: is your organization ready for beyond budgeting? Measuring Business Excellence, 9(2), 56-67. https://doi.org/10.1108/13683040510602885

Waal, A., Hermkens-Janssen, M., \& Ven, A. (2011). The Evolutionary Adoption Framework: Explaining the Budgeting Paradox. Journal of Accounting and Organizational Change, 7(4), 316-336. https://doi.org/10.1108/18325911111182295

\section{Copyright Disclaimer}

Copyright for this article is retained by the author(s), with first publication rights granted to the journal.

This is an open-access article distributed under the terms and conditions of the Creative Commons Attribution license (http://creativecommons.org/licenses/by/3.0/). 